\title{
Programmed Death-1(PD-1), a correlate of protection against disease progression in HIV-1 infected long-term non-progressors
}

\author{
J Kyosiimire-Lugemwa
}

From AIDS Vaccine 2012

Boston, MA, USA. 9-12 September 2012

\section{Background}

Long-Term Non-Progressors (LTNP) control HIV-1 disease progression but correlates of control are not clear. T-cell activation and expression of Programmed Death-1 (PD-1), a marker of $\mathrm{T}$-cell inhibition/exhaustion, have been suggested as markers of progression to AIDS. We assessed levels of T-cell activation and PD-1 in LTNP and Rapid progressors (RP).

\section{Methods}

We recruited 15 LTNP and 15 RP originally enrolled in the Entebbe Cohort in Uganda. All were ART naïve and 29 were women. HLADR , CD38 and PD-1 levels were assessed in CD4, CD8 and CD45RA T-cells by flow cytometry. HIV-1 disease progression markers: plasma lipopolysaccharide (LPS) levels, HIV-1 RNA viral load (VL), HIV-1 pro-viral DNA load (PVL) and CD4 counts at enrollment were quantified. Comparisons between groups were performed using the Mann-Whitney $U$ test and correlations by Spearman's linear correlation coefficients.

\section{Results}

Activated (HLADR+CD38+) CD4+CD45RA+ were higher in the LTNP (median $0.64 \%$ for LTNP and $0.18 \%$ for RP, $\mathrm{p}=0.03)$. PD- 1 expression in the CD4 and CD8 T-cell subsets was higher in the LTNP (CD4+PD-1+ median 39.6\% for LTNP and 1.0\% for RP, $\mathrm{p}=0.001$; CD8 $+\mathrm{PD}-1+$ median $60.8 \%$ for LTNP and $13.5 \%$ for RP, $\mathrm{p}=0.003)$. VL ( $\mathrm{p}=0.05)$, PVL $(\mathrm{p}=0.03)$, LPS $(\mathrm{p}=0.005)$ were higher in the RP and enrollment CD4 count ( $\mathrm{p}=0.0002)$ was higher in the LTNP. VL, PVL and LPS positively associated with each other and all negatively associated with enrollment CD4 count. CD4+PD-1+ correlated

MRC/UVRI Uganda Research Unit on AIDS, Kampala, Uganda negatively with VL ( $\mathrm{rs}=-0.40, \mathrm{p}=0.03)$, LPS $(\mathrm{rs}=-0.38$, $\mathrm{p}=0.04$ ) and positively with enrollment $C D 4$ count $(\mathrm{rs}=0.36, \mathrm{p}=0.05) . \mathrm{CD} 4+\mathrm{CD} 45 \mathrm{RA}+\mathrm{HLADR}+\mathrm{CD} 38+$ correlated positively with enrollment $\mathrm{CD} 4$ counts $(\mathrm{rs}=0.38$, $\mathrm{p}=0.04$ ). Positive correlations were observed between CD4 +CD45RA+/-HLADR+CD38+, CD8+CD45RA+HLADR +CD38+ and CD4+PD-1+ and CD8+PD-1+ T-cells.

\section{Conclusion}

Co-expression of PD-1 and activation markers was higher in the LTNP compared to the RP, contrary to other studies. PD-1 correlated with markers of protection against HIV-1 disease progression, suggesting a beneficial role for PD-1.

Published: 13 September 2012

doi:10.1186/1742-4690-9-S2-P254

Cite this article as: Kyosiimire-Lugemwa: Programmed Death-1(PD-1), a correlate of protection against disease progression in HIV-1 infected long-term non-progressors. Retrovirology 2012 9(Suppl 2):P254.

Submit your next manuscript to BioMed Central and take full advantage of:

- Convenient online submission

- Thorough peer review

- No space constraints or color figure charges

- Immediate publication on acceptance

- Inclusion in PubMed, CAS, Scopus and Google Scholar

- Research which is freely available for redistribution

\section{Ciomed Central}

